\title{
Sacred geography in Kazakhstan: commemorative policy of the state and local practices in public spaces
}

DOI: $10.31551 / 2410-2725-2018-4-3-438-447$

\section{Medeuova Kulshat}

Doctor of Philosophy, Professor of the Department of Philosophy in L.N. Gumilyov Eurasian National University. Republic of Kazakhstan, 010000 Astana, Yanushkevich street 6. E-mail: mkulshat@mail.ru

\section{Sandybayeva Ulbolsyn}

Candidate of Philosophy, Associate Professor of the Department of Philosophy in L.N. Gumilyov Eurasian National University. Republic of Kazakhstan, 010000 Astana, Yanushkevich street 6. E-mail: ulbolsyn.sandybaeva@gmail.com

\begin{abstract}
The article discusses some aspects of discussions about memorial complexes-mazars, two field cases representing the current commemorative situation, in which both ideological discourse and local memory practices are reflected. The connection of the modern commemorative situation with the implementation of the state program «Sacred Geography of Kazakhstan» is considered.

The article was carried out within the framework of the project «Places of Memory» in the contemporary culture of Kazakhstan: the processes of commemoration in public spaces. While writing the article, the data obtained during field research were used.

Keywords: sacral geography; commemorative politics; memorial complexes; mazars; memory practices; identity.

\section{Қазақстанның қасиетті географиясы: мемлекеттің коммеморативті саясаты және қоғамдық орындардағы жергілікті тәжірибе}

\section{Медеуова Кульшат Агибаевна}

Философия ғылымдарының докторы, Л.Н. Гумилев атындағы Еуразия ұлттық университетінің фрилософия кафедрасының профессоры. Қазақстан Республикасы, 010000, Астана қ, Янушкевич к, 6. E-mail: mkulshat@mail.ru

\section{Сандыбаева Улболсын Майтановна}

фрилософия ғылымдарының кандидаты, Л.Н. Гумилев атындағы Еуразия ұлттық университетінің философия кафедрасының доценті. Қазақстан Республикасы, 010000, Астана, Янушкевич к, 6. Еmail: ulbolsyn.sandybaeva@gmail.com

Аңдатпа. Мақалада мемориалдық кешендердің талқылануының кейбір аспектілері талқыланады, қазіргі кездегі есте сақтау жағдайларын білдіретін екі өріс жағдайында идеологиялық дискурс пен жергілікті жад тәжірибесі көрсетіледі. Мақала ««Естелік орындары» Қазақстанның қазіргі заманғы мәдениетінде: қоғамдық кеңістіктердегі еске алу үдерістері» жобасының аясында өткізілді. Мақаланы жазған кезде, далалық зерттеулер барысында алынған деректер пайдаланылған.

Түйінді сөздер: қасиетті география, коммеморативті саясат, мемориалды кешендер, мазарлар, жады тәжірибесі, бірегейлік.

\section{Сакральная география в Казахстане: коммеморативная политика государства и локальные практики в публичных пространствах}

\section{Медеуова Кульшат Агибаевна}

доктор философских наук, профессор кафедры философии Евразийского национального университета имени Л.Н. Гумилева. Республика Казахстан, 010000, Астана, ул. Янушкевича 6. Еmail:mkulshat@mail.ru

\section{Сандыбаева Улболсын Майтановна}

кандидат философских наук, доцент кафедры философии Евразийского национального университета имени Л.Н. Гумилева, Республика Казахстан, 010000 Астана, ул. Янушкевича 6. E-mail: ulbolsyn.sandybaeva@gmail.com 
Абстракт. В статье рассмотрены некоторые аспекты дискуссий о мемориальных комплексахмазарах, два полевых кейса, репрезентирующие актуальную коммеморативную ситуацию, в которых отражается и идеологический дискурс, и локальные практики памяти. Рассмотрена связь современной коммеморативной ситуации с реализацией государственной программы «Сакральная география Казахстана».

Статья выполнена в рамках проекта ««Места памяти» в современной культуре Казахстана: процессы коммеморации в публичных пространствах». При написании статьи использовались данные, полученные в ходе полевых исследований.

Ключевые слова: сакральная география; коммеморативная политика; мемориальные комплексы; мазары; практики памяти; идентичность.

Удк 130.2(574)

\section{Сакральная география в Казахстане: коммеморативная политика государства и локальные практики в публичных пространствах}

\section{К.А. Медеуова, У.М. Сандыбаева}

В программной статье Нурсултана Назарбаева «Взгляд в будущее: модернизация общественного сознания» артикулирована новая коммеморативная политика государства через такие ключевые понятия как «культурный код нации», «каркас национальной идентичности», «туған жер» (малая родина), «сакральная географрия Казахстана» (Назарбаев, 2017). Подобная активная идеолого-методологическая инвестиция позволила выйти из тени достаточно большому пулу тем, вопросов, проблем, ранее умалчивавшихся официальной отечественной гуманитаристикой. В статье ставится оппозиция между влиянием «глобального мира» и проблемами национальной идентичности, сохранения культурного наследия, в связи с чем, Президент РК заявил о необходимости программы «Сакральная география Казахстана», которая по замыслу должна создать «культурно-географический пояс святынь Казахстана» (Назарбаев 2017). Оператором проектов по сакральной географии был определен Научно-исследовательский центр «Сакральный Казахстан». Центр прежде всего должен был решить ряд организационных задач: сформировать карту сакральных объектов Казахстана; разработать комплекс мер по изучению и популяризации объектов "Сакрального пояса Казахстана», повышению их привлекательности в качестве объектов туристской деятельности; разработать программу развития внутреннего туризма, включая такие направления как паломнический, культурно-познавательный и этнографический туризм.

В интеллектуальном плане центр ставит задачу активизации исследований «скрытых», «вытесненных», а также локальных «краеведческих» тем, популяризации устной истории, описания паломнических практик и географии сакральных мест в виде многотомной энциклопедии. Выбранный подход направлен на актуализацию традиционных систем знаний о сакральных практиках и сакральных местах в Казахстане, на применимость в процессах модернизации потенциала духовного наследия, на расширение представлений о культурной и интеллектуальной истории Евразийского континента.

За первый год работы центра были получены результаты публикации двух монографий: «Сакральные объекты Казахстана общенационального значения» (Сакральные объекты 2017) и «Региональные сакральные объекты Казахста- 
на» (Религиозные сакральные объекты 2017).

В представленной статье рассматриваются два полевых кейса по объектам западного и северного Казахстана, вошедших в реестры первого тома, а значит объектов, представляющих общенациональное значение. Первый кейс связан с мемориальным комплексом Адай-Ата на горе Отпан-тау в Мангыстау, второй - с мемориальным комплексом Карасай и Агынтай батыров, находящегося в другой части Казахстана - в Айыртауском районе Северо-Казахстанской области.

Под сакральными объектами общенационального значения понимаются «особо почитаемые памятники природно-ландшафтного и культурного наследия, светской и культовой архитектуры, мавзолеи, а также места, связанные с историческими и политическими событиями, имеющими непреходящую ценность в памяти народа Казахстана» (Сакральные объекты, 2017). Внутри этой номинации есть разделение на пять подгрупп: особо почитаемые памятники природного наследия; археологические памятники и средневековые городские центры; религиозные и культовые объекты, являющиеся местами поклонения; сакральные места, связанные с историческими личностями; сакральные места, связанные с историческими и политическими событиями.

Разделение на доисламский и исламский периоды истории Казахстана позволяет выделять особые сакральные места, связанные с исламом -

«әулие». Терминологически эти места могут обозначаться как киелі жер, әулие жер, зират орны, әулие орны. Главным здесь является то, что данное место связано с деятельностью и местом захоронения мусульманских святых әулие. Сакральные места, связанные с объектами исламского религиозного культа, могут быть мазарами, мавзолеями, храмами, мечетями, медресе, зиратами и другими территориями, прилегающими к главной святыни этой территории - чаще всего могилами святых. Такие места также связаны с деятельностью особого религиозного сословия - шайх, шырақшы, которые чаще всего являются потомками святых әулие. Эти места обладают особым статусом могил и зирата, и практиками почитания.

Мазары, деревья и другие сакральные места, связанные с паломничеством, могут иметь дополнительные атрибуты, несвойственные исламским практикам - ақтық - использование белых полотнищ, фрлагов для маркировки мазара или же ленточки, лоскутки для маркировки деревьев, родников, пещер, гротов.

Следует отметить, что в научной литературе существуют разные подходы к определению святых мест и к тому, как их следует изучать. Аширбек Муминов предлагает достаточно детальную типологию святых мест в Центральной Азии в контексте исламской нарратологии (Муминов, 1996). Сергей Абашин в описании типичных и нетипичных святых мест на основе своих полевых исследований делает вывод о том, что неопределенность сакрального статуса, разнообразие практик, легенд о святых - типичная характеристика мазаров (Абашин 2013). Результаты собственных полевых исследований показывают, что позиция Абашина представляется как более релевантная для казахстанского поля. Так, нами было выявлено, что акторами процессов коммеморации являются не только государственные институции, но и местные сообщества, религиозные конфессии, бизнес-структуры, представители родов. Практики памяти и многообразные дискурсы, явные и неявные тенденции периода независимости Казахстана описаны в коллективной монографии «Практики и места памяти в Казахстане» именно как гибридные сюжеты мемориальной культуры (Медеуова и др. 2017). 
Сакральные места, связанные с объектами христианских конфессий, также многообразны и многоплановы. Помимо городских храмов имеются монастыри, пустоши (скиты), могилы святых мучеников, места трагической гибели невинноубиенных и экуменистические памятные знаки. В православии активно используется практика «воспроизведения святости» - паломничество к иконам, которые могут перемещаться от храма к храму, от региона к региону. В этом плане Казахстан является территорией, через которую проходят транснациональные паломнические потоки.

Наиболее популярными практиками памяти сегодня являются паломничества к святым местам. Как в христианских, так и в исламских практиках паломничества происходит смещение акцентов, гибридизация дискурсов. В целом эти практики мотивированы стандартным набором в виде: исцеление болезней, получение благословения (бата), связи с прошлым. Однако места паломничества не являются аполитичными. На это указывает антрополог Улан Бегожин, основываясь на полевых исследованиях мазарного комплекса «Акколь» в Павлодарской области. По его наблюдениям для поддержания и расширения святынь хранители (шыракши) ищут покровительство у политических и экономических элит. Возникают и конфликтные ситуации между хранителями и меценатами. Все это свидетельствуют о том, что светские и сакральные практики оказываются взаимозависимыми (Бегожин 2018).

Сакральные места с активными практиками памяти: мемориалымазары. Одним из самых активных социальных пространств с разноуровневыми практиками памяти является мемориальный комплекс Отпан-тау в Мангыстау. Всего за несколько лет он стал самым узнаваемым сакральным местом и своеобразным «новым» символом общенационального единства, где предпринимаются попытки различными акторами усилить его сакральность от локальной к общенациональной.

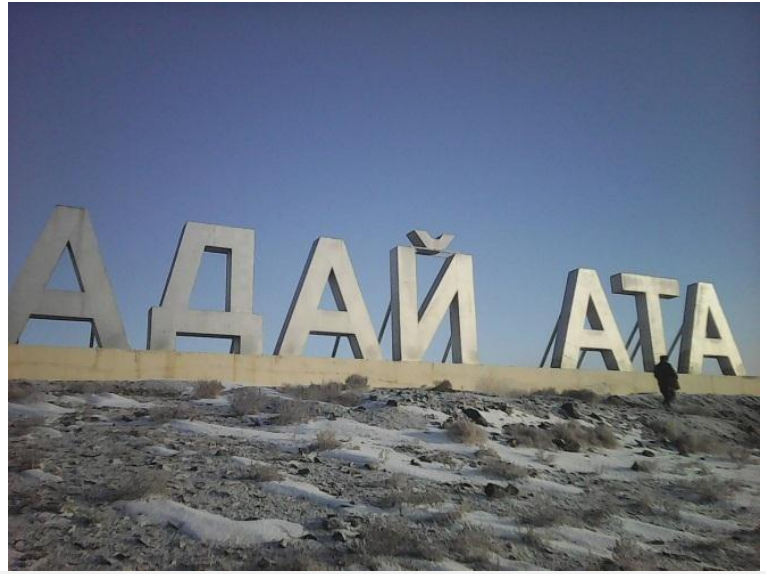

Рисунок 1. Гора Отпан тау, комплекс Адай ата
Адаи построили мемориал в память о своем предке Адай ата на мемориальной горе Отпан тау, и проводят разного рода крупные, общественные мероприятия, среди которых празднование Амал (наступление весны) является самым значимым, широко транслируемым всеми средствами СМИ. На этот праздник зажигают огонь, который получил название Огня единства, что свидетельствует о заинтересованности государства в сохранении подобных практик.

Вокруг идеи и практики зажигать огонь на горе сложились разные нарративы, отсылающие к зароастрийским корням, суфиииским практикам или рассматривающие его как сигнальный костер и призыв к отпору врагам. Один из идеологов создания комплекса Сабыр Адай называет этот огонь «Ұран-От» - «Огонь-Призыв, Боевой клич» (Адай 2014). Поэтому он полагает, что на горе должен быть представлен и памятник всем казахским батырам «Алаш батыры». 
По мнению Зиры Наурызбаевой, исторически Отпан-тау был караульной горой, на которой туркмены, а затем и завоевавшие в XVIII веке полуостров адаи несли караул и в случае вторжения врага зажигали «Ұран от» сигнальный костер (Наурызбаева 2018). Сохранились легенды об адайском батыре Ер Төлепе, котоорый нес караул на горе. В советское же время это место являлось рядовым объектом. «Но по словам краеведа, прямого потомка Ер-Толепа Мурата Акмырзаева в некоторых семьях, например, в их собственной, была традиция изредка посещать эту гору, совершать восхождение на нее, устраивать для родственников садақа - поминальный дастархан» (Наурызбаева 2018).

Комплекс создавался благодаря поддержке местных бизнесменов, нефртяных компаний. Мемориал представляет из себя 37-ми метровую башню предку рода адай Адай-ата и две башни поменьше размером в честь его сыновей. Внутри мазара находится символическое надгробие. Рядом с мавзолеем установлена гигантская чаша, в которой на праздник Амал в ночь с 13 на 14 марта зажигают Огонь единства. Чашу поддерживает своеобразный треножник, символизирующий три казахских жуза (Наурызбаева 2018). Рядом скульптура волка Көкбөрі - символ свободы и силы. Как и во многих сакральных местах здесь можно увидеть сухое дерево Әулие ағаш, на которое паломники повязывают куски ткани. Идею единства должны репрезентировать два знамени - знамя адаев и фрлаг Казахстана, которые установят на второй вершине Отпан-тау - Тұтөбе. Эта священная гора символизирует Великую мать, возможно поэтому установлена здесь стела с женской фригурой, напоминающей балбал. Как пишет Наурызбаева, «в адайских эпических произведениях, в генеалогии адаев значимое место занимает праматерь Ханбиби, которая зачала сына Адая от Света и родила на берегу Родник Света - Нұрбұлақ. Это чудесное рождение описывается и в эпических произведениях начала XX века» (Наурызбаева 2018).

У подножия горы имеется еще один комплекс Қарашаңырақ, т.е. Шанырак предков, а также Қараказан - уменьшенная копия тайқазана из Мавзолея Яссави в Туркестане. Комплекс имеет определенную инфракструктуру для приема паломников и туристов.

Особенностью этого мемориального комплекса является то, что благодаря инвестициям со стороны крупных сырьевых компаний родовой праздник транссрормируется в общенациональный и с каждым годом возрастает интерес к нему, причем организацией праздника занимаются все адайские роды по очереди.

Например, в 2018 году в соответстви с Программой празднования Амал в церемонии зажжения Огня единства приняли участие представители восьми казахстанских музеев и заповедников: Коркыт ата (Кызылординская область), Азирет Сұлтан (Туркестан), Хан ордалы Сарайшық (Атырауская область), Бекет ата (Мангистауская область), Ұлытау (Карагандинская область), Мәшһүр Жүсіп (Павлодарская область), Жидебай Бөрілі (Восточно-Казахстанская область), Ақмешіт (Южно-Казахстанская область) (Программа празднования Амал 2018). Все эти мемориалы являются сакральными местами и представляют разные регионы Казахстана. В данном случае мы видим как государство использует в процессах нациостроительства локальные сакральные места памяти.

Второй кейс менее известен для всего Казахстана - это мемориальный комплекс Карасай и Агынтай батыров, находящийся в другой части Казахстана - в Айыртауском районе Северо-Казахстанской области. В его строительстве также использовалась идея единства народа. Комплекс включен в Список са- 
кральных мест Северо-Казахстанской области. По формальному критерию его относят к сакральным местам, связанным с историческими личностями, однако сегодня он напоминает больше место паломничества, связанного с различными практиками религиозного, эзотерического характера. Паломничества к мавзолеям батыров носит массовый характер, причем наблюдается много туристов и паломников из пограничных регионов России.

В ходе полевого исследования поездка к мазару сопровождалась остановками у могил аулие, которые встречались на пути. Причем эти остановки, по мнению сопровождающего местного водителя, являются обязательными, иначе у «паломников» могут возникнуть трудности, неприятности в пути. Таким образом, посещение одного «официального объекта», меморизирующего батыров, дополняется посещением зиратов трех аулие. На всех мазарах паломнику предлагается взять белый кусок ткани, которыми плотно обвешаны мазары, в дальнейшем эти ткани необходимо использовать при плохом самочувствии, болезнях и тому подобное.

На одном из зиратов наблюдалась группа людей, уже завершавших обряд. Они поднимались с земли и в руке одного из мужчин был кнут, что также относится по местным представлениям к практикам «дополнительной, фетишной сакрализации».

Стандартный коллективный паломнический ритуал проходит следующим образом. Необходимо по «команде» сопровождающего лечь на землю и семь раз перевернуться, перекатываясь по земле, и затем полежать с закрытыми глазами. При этом «сопровождающий», который одновременно является водителем, гидом и адептом, спрашивает, какие цвета видят паломники. После этого он читает суру Корана, предупреждая о том, что у каждого аулие нужно просить определенные вещи, к одному обращаться с просьбами по «бумажным», денежным вопросам, потому что он был бием, у другого просить здоровья и другие блага.

В пути от одного мазара к другому, сопровождающий все больше и больше «управляет» своей мини-группой. Он говорит о том, что посещение двух батыров Карасай и Агынтай и трех «ата» можно оценивать как посещение пяти ата: «Карасай, Агынтай, Мендыбай, Жанаби ата, Науан Хазрет ата», что, согласно местному канону, позволяет рассчитывать на получение благодати, поскольку в итоге произойдет посещение пяти «ата». Судя по риторике проводника, наблюдаемые практики с использованием белой ткани на мазарах, имеют отношение к религиозному течению «Ата жол», к которому как государство, так и официальный ислам настроены критично.

Мемориальный комплекс Карасай и Агынтай батыров интересен тем, что здесь захоронены батыры из разных родов: Агынтай бытыр из рода аргын Среднего жуза и Карасай батыр из рода шапрашты Старшего жуза («Наш президент его же прямой потомок» - говорит проводник). Эти батыры воевали вместе против джунгар в XVII веке и были друзьями, что отражено на табличках, расположенных в зале между мазарами: «49 лет из 73 лет своей жизни провел Карасай батыр со своим полувековым другом Агынтаем в сражениях. Настоящий памятник-мавзолей воздвигнут в 1999 году благодарными потомками батыров суверенной Республики Казахстан, получившей подлинную независимость в 1991 году».

Сам мемориальный комплекс представляет из себя две высокие конусообразные башни, напоминающие шлемы батыров, символически соединенные поминальной мечетью. Соответственно в каждой башне гранитные надгробия 
- традиционные кулпытас (стела) и койтас (стилизованное в виде барана ступенчатое надгробие), а также шарак - светильник, зажигая который можно об-

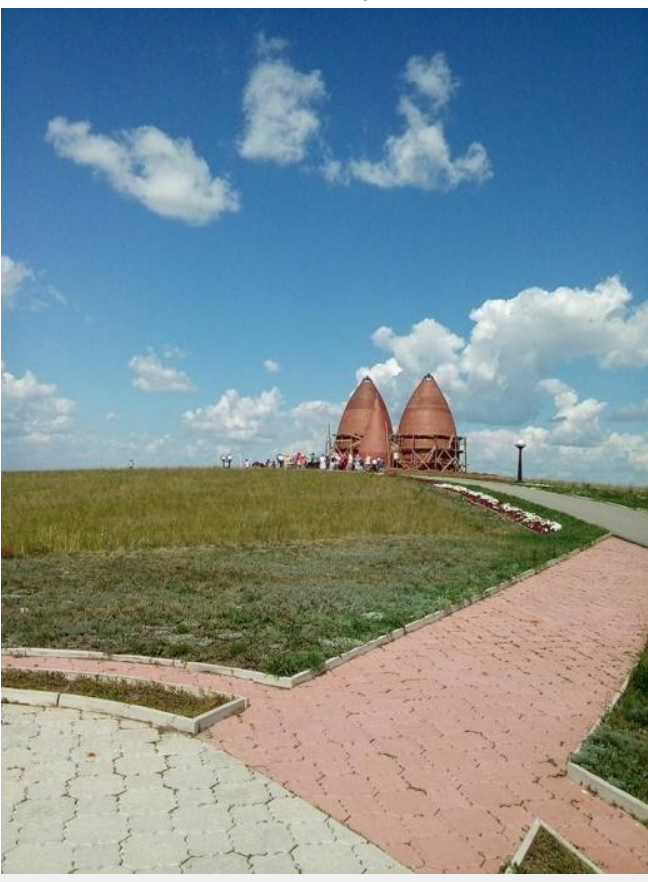

Рисунок 2. Мемориальный комплекс Карасай и Агынтай батыров ращаться к аруахам. При входе в мазар у надгробия расположена длинная лавочка для посетителей. Ширакшы каждой группе читает суры из Корана. Следует отметить экспрессивную и очень громкую манеру чтения шыракшы, словно он входит в транс, что в сравнении с другими полевыми данными, встречается не так часто.

Справа от башни Карасай батыра расположены могилы двух его детей. Весь комплекс расположен на сопке Кулшынбай-тобе и огражден забором. Перед входом в комплекс можно приложить ладонь к раскрытой книге, сделанной из гранита, с текстом суры на одной странице на казахском языке, на другой - на арабском. Подобное можно увидеть и на других мазарах. Дорога, ведущая к сопке с мазарами, асфальтирована. Для паломников и посетителей имеются гостиные дома, помещения для омовения, специальное оборудованное пространство для жертвоприношения и приготовление поминальной еды. По рассказам местных, рядом с мемориалом находятся многочисленные захоронения воинов, и обнаружены останки двухметрового батыра с тяжелыми доспехами.

По классификации Муминова, данный мемориал-мазар можно отнести к категории «с мавзолеем и мечетью». Если же исходить из принципа «популярности», то он не вписывается в предложенные рамки, поскольку не известен в Центральной Азии. В тоже время его нельзя ограничить регионом, поскольку он также популярен в соседних областях России.

Возникает вопрос и о статусе святости, ведь мемориал воздвигался батырам как историческим личностям, защитникам народа от врагов, по крайней мере, по замыслу государства. В летний период здесь можно увидеть множество палаток, юрт, автобусов и легковых автомобилей. Паломники собираются вокруг какого-нибудь человека, читающего проповедь, дающего личное бата (благословение) или совершающего какой-нибудь ритуал. Наблюдение за несколькими группами, собравшимся в круг в степи, вдоль дороги к мазару, выявило доминирование в них женщин.

Несмотря на то, что мавзолей Карасай и Агынтай батыров полностью создан на средства государства, поддерживающего общую коммеморативную логику восхваления батыров, так, например, о Карасае батыре говорят, что он был наделен особым даром, его всюду сопровождал священный барс и что он помогает просящим, прежде всего, в делах карьеры, в решении «бумажных вопросов», объект представляет интерес именно как транснациональный. Сюда приезжают представители различных этносов и конфессий с разными мотивами. Из соседних сел приезжают молодожены, выпускники школ со своими просьбами, за благословением, наблюдается много женщин среднего 
возраста, их просьбы часто связаны со здоровьем, рождением детей, семейными проблемами. С другой стороны, для государства этот комплекс сим

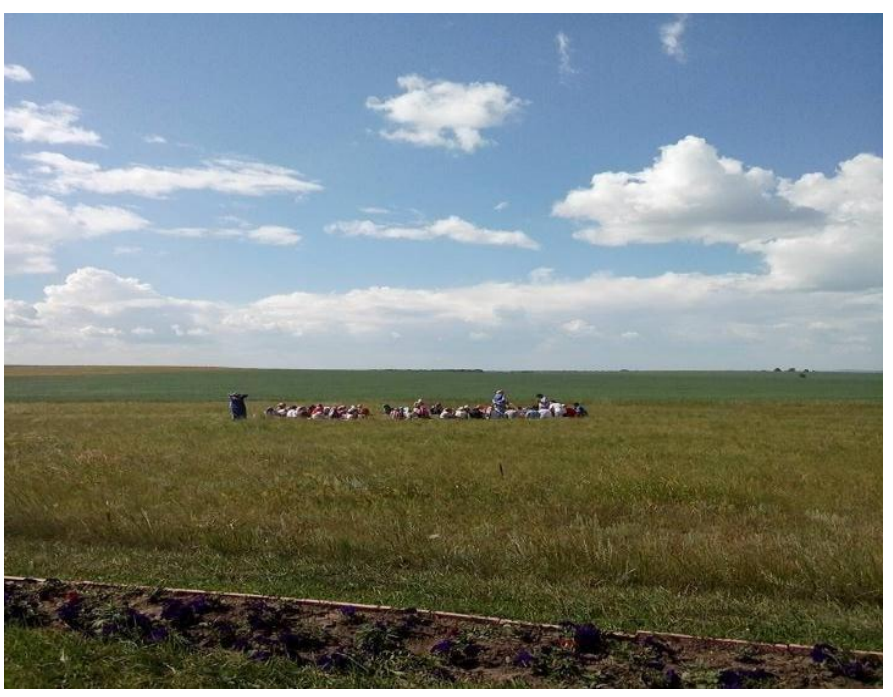

Рисунок 3. Группы паломников у мемориального комплекса волизирует идею единства народа - два батыра с разных жузов боролись вместе против врагов.

Сравнивая характер паломничества, сакрализирующие приемы, способы апроприации ландшафтного пространства в качестве публичного, отмечаем, что наиболее успешными, яркими, видимыми являются те практики, которые ресурсно подготовлены. Так наличие крупных сырьевых компаний, меценатов на западе Казахстана позволило создать/воссоздать более масштабные рекон-

струкции сакральных сценариев. Успешность Адай горы в сравнении с сопкойКулшынбай-тобе - это также успешность более герметического сценария коллективной памяти, поскольку речь исходно идет о коллективной памяти рода, а затем она уже вступает в символический обмен с государством.

Общая характеристика сакральных объектов с природно-ландшафтным сопровождением, будь то горы, долины, пещеры, реки, урочища, одиночные деревья, пустыни, древние городища, места необычных природных явлений, всегда имеет «лучшую» практику сакрализации пространства, потому что мифологические корни и сохраненные эпико-поэтические фрормы транслируют представления о сакральных топосах. Поэтому позиционирование горы Отпантау в качестве самого брендированного объекта сакральной географии является очевидным.

Одной из особенностей природно-ландшафтных сакральных пространств и конкретных сакральных мест является то, что они связаны с основными путями миграции народов и известными караванными маршрутами взаимодействия древних культур и цивилизаций. Поэтому транскультурные регионы отличает глубина и плотность исторической памяти, проявляющиеся в многообразных артефактах культур разных эпох: в курганах и менгирах, ритуальных комплексах и петроглифах, часовнях и монастырях, мазарах, камалах, памятных знаках и зиратах. Мазары, мавзолеи, құлыптасы (стелы, скульптурные столбы), қойтасы (надгробные камни), сандықтасы (кенотафы), пограничные башни это все материальные знаки социальной, духовной эволюции степи на протяжении многих веков. Сакральные места могут выполнять и демаркационную роль, быть знаками в пространстве для обозначения родовых территорий, направлений кочевок. В таких местах используются тотемные атрибуты, тамгообразные изображения, камалы, балбалтасы, құлыптасы.

Понимание значимости сакральных мест основывается на целостном (универсальном) знании. Сакральные места - «қасиетті» - не существуют сами по себе, они всегда соотносятся с определенными системами иерархически организованных знаний. Родовые отношения в некоторой степени являются соци- 
альным капиталом, который вновь актуализируется и интерпретируется в идеологическом контексте. Знание о происхождении и родовых связях сохраняют свою ценность в качестве культурного капитала, позволяющего обладать неким статусом. Для государства важны идеи единства народа, общей идентичности, поэтому оно апеллирует к национальным героям, батырам, аулие, и лояльно относится к локальным, региональным артикуляциям, если они также поддерживают идею целостности «культурно-географического пояса святынь в качестве «символической защиты» страны.

\section{Әдебиеттер тізімі/ Список литературы}

1. Абашин С. Мазар Бобои-об: о типичности и нетипичности сакральных мест Средней Азии [Электронный ресурс] // Электронная библиотека Музея антропологии и этнографии им. Петра Великого (Кунсткамера) PAH. www.kunstkamera.ru/lib/rubrikator/03/03_03/978-5-55431-158-9/ (Дата обращения: 5.09.2018)

2 Bigozhin U. Local Politics and Patronage of a Sacred Lineage Shrine in Kazakhstan // Central Asian Affairs. - Vol.5. - Issue 3. - P.233-252.

3. В Казахстане сейчас идет бум святых мест [Электронный ресурс] // kozhalar.kz Tapих. Талым. Тағылым. - URL: www.kozhalar.kz/20174088-v-kazahstane-sejchas-idet-bum-svyatyh-mest (Дата обращения: 28.08.2018).

4. Геллнер Э. Нации и национализм. [Электронный ресурс] // gumer.info. Библиотека Гумер. URL: www.gumer.info/bibliotek_Buks/Polit/gelln/12.php (Дата обращения: 28.08.2018).

5. Медеуова К.А., Сандыбаева У.М., Наурызбаева З.Ж., Толгамбаева Д.Т., Ермаганбетова К.С., Мельников Д.Н., Кикимбаев М.Ж., Рамазанова А.Ч., Тлепберген А.Б., Жетибаев Е.Ж., Оразбаева Д.Е., Полтавец К.А. Практики и места памяти в Казахстане. - Астана: ЕНУ им. Л.Н. Гумилева, 2017. - 320 c.

6. Муминов А. Святые места в Центральной Азии (взаимодействие исламских и местных элементов). - Маяк Востока. - 1996. - №1-2. - С.14-21.

7. Назарбаев Н.А. Взгляд в будущее: модернизация общественного сознания // Казахстанская правда. - 2017. - 12 апреля.

8. Наурызбаева 3. Отпан-тау - Караульная гора эпохи глобализации? [Электронный ресурс] // www.inaktau.kz - URL: www.otuken.kz (Дата обращения: 2.09.2018)

9. Программа празднования Амал на Отпан-тау. [Электронный ресурc] // www.inaktau.kz - URL: www.inaktau.kz/news/1978138/programma-prazdnovania-amal-na-otpan-tau]. (Дата обращения: 6.09.2018 г.)

10. Региональные сакральные объекты Казахстана. - Астана: Фолиант, 2017. - 504 с.

11. Сакральные объекты Казахстана общенационального значения. - Астана: Фолиант, 2017. $496 \mathrm{c.}$

12 Филиппова Е. История и память в эпоху господства идентичностей. (Интервью с действительным членом Французской Академии историком Пьером Нора) // Этнографическое обозрение. - 2011. - №4. - С.75-84.

\section{Reference}

Abashin Nd - Abashin, S Nd, Mazar Boboi-ob: o tipichnosti inetipichnosti sakral'nyh mest Srednej Azii, EHlektronnaya biblioteka Muzeya antropologii i ehtnografii im. Petra Velikogo (Kunstkamera) RAN retrieved 5 of September 2018, <www.kunstkamera.ru/lib/rubrikator/03/03_03/978-5-55431-1589/> (Abashin, S Nd, Mazar Boboi-about: on the typical and atypical nature of the sacred places of Central Asia, Electronic library of the Museum of anthropology and Ethnography. Peter the Great (Kunstkamera) retrieved 5 of September 2018, <www.kunstkamera.ru/lib/rubrikator/03/03_03/978$5-55431-158-9 />)$. (in Rus).

Bigozhin 2018 - Bigozhin, U 2018, Local Politics and Patronage of a Sacred Lineage Shrine in Kazakhstan, Central Asian Affairs, Volume 5, Issue 3, P.233-252. (in Eng).

V Kazahstane sejchas idet 2018 - In Kazakhstan now there is a boom of Holy places 2018, kozhalar.kz retrieved 28 of August 2018, <www.kozhalar.kz/20174088-v-kazahstane-sejchas-idet-bum-svyatyh-mest> (V Kazahstane sejchas idet bum svyatyh mest. 2018, kozhalar.kz retrieved 28 of August 2018, $<$ www.kozhalar.kz/20174088-v-kazahstane-sejchas-idet-bum-svyatyh-mest>). (in Eng).

Gellner Nd - Gellner, E Nd, Nacii i nacionalizm, www.gumer.info retrieved 18 of August 2018, <www.gumer.info/bibliotek_Buks/Polit/gelln/12.php>. (Gellner, E Nd, Nacii i nacionalizm, 
$\begin{array}{lllll}\text { www.gumer.info } & \text { retrieved } & \text { of } & \text { August }\end{array}$ $<$ www.gumer.info/bibliotek_Buks/Polit/gelln/12.php>). (in Rus).

Medeuova, Sandybaeva, Nauryzbaeva 2017 - Medeuova, KA, Sandybaeva, UM, Nauryzbaeva, ZZh, Tolgambaeva, DT, Ermaganbetova, KS, Mel'nikov, DN, Kikimbaev, MZh, Ramazanova, ACh, Tlepbergen, AB, Zhetibaev, EZh, Orazbaeva, DE, Poltavec, KA 2017, Praktiki i mesta pamyati v Kazahstane, Astana: L.N. Gumilev ENU, 320 p. (Medeuova, KA, Sandybaeva, UM, Nauryzbaeva, ZZh, Tolgambaeva, DT, Ermaganbetova, KS, Mel'nikov, DN, Kikimbaev, MZh, Ramazanova, ACh, Tlepbergen, AB, Zhetibaev, EZh, Orazbaeva, DE, Poltavec, KA 2017, Practices and places of memory in Kazakhstan, Astana: L.N. Gumilev ENU, 320 p). (in Rus).

Muminov 1996 - Muminov, A 1996, Svyatye mesta v Central'noj Azii (vzaimodejstvie islamskih i mestnyh ehlementov), Mayak Vostoka, №1-2, P.14-21. (Muminov, A 1996, the Holy places In Central Asia (interaction of Islamic and local elements), The Lighthouse of the East, №1-2, P.1421). (in Rus).

Nazarbaev 2017 - Nazarbaev, NA 2017, Vzglyad v budushchee: modernizaciya obshchestvennogo soznaniya, Kazakstan true, 12 aprelya. (Nazarbaev, NA 2017, A look into the future: modernization of public consciousness, Kazakstan true, 12 aprelya). (in Rus).

Nauryzbaeva Nd - Nauryzbaeva, Z. Nd, Otpan-Tau-the Guard mountain of globalization era? www.otuken.kz retrieved 2 of September 2018, <www.otuken.kz> (Nauryzbaeva, Z. Nd, Otpantau - Karaul'naya gora ehpohi globalizacii?, www.otuken.kz retrieved 2 of September 2018, $<$ www.otuken.kz>). (in Rus).

Programma prazdnovaniya Nd - Programma prazdnovaniya Amal na Otpan-tau, inaktau.kz retrieved 6 of September 2018, <www.inaktau.kz/news/1978138/programma-prazdnovania-amal-na-otpantau>. (The program of celebration at Amal Otpan-Tau, $<$ www.inaktau.kz/news/1978138/programma-prazdnovania-amal-na-otpan-tau>). (in Rus).

Regional'nye sakral'nye 2017 - Regional'nye sakral'nye ob"ekty Kazahstana 2017, Foliant, Astana, 504 p. (Regional sacred objects of Kazakhstan 2017, Foliant, Astana, 504 p.). (in Rus).

Sakral'nye ob'ekty Kazahstana 2017 - Sakral'nye ob'ekty Kazahstana obshchenacional'nogo znacheniya 2017, Foliant, Astana, 496 p. (Sacred objects of Kazakhstan of national importance 2017, Foliant, Astana, 496 p). (in Rus).

Filipova 2011 - Filipova, E 2011, Istoriya i pamyat' v ehpohu gospodstva identichnostej. (Interv'yu s dejstvitel'nym chlenom Francuzskoj Akademii istorikom P'erom Nora), Ethnography review, №4, P.75-84. (Filipova, E 2011, History and memory in the era of domination of identities. (Interview with a full member of The French Academy historian Pierre Nora), Ethnography review, №4, P.7584). (in Rus). 